\title{
Physicochemical quality of araçaúna and grumixama at different ripening stages
}

\author{
Bruna Lara Alvarenga Barros ${ }^{1}$, Moises Zucoloto², Sarah Ola Moreira ${ }^{3}$, \\ Tiago de Oliveira Godinho ${ }^{4}$, Stanley Bravo Buffon ${ }^{5}$, Andreia Lopes de Morais ${ }^{6}$
}

\begin{abstract}
The physicochemical characteristics of fruits of species native to the Atlantic Forest are little known, especially during ripening. The aim of this work was to evaluate the effect of the interaction between ripening period and post-harvest storage of araçaúna and grumixama. Fruits were harvested at three ripening stages: green, partially ripe and ripe, according to the epicarp color, and separated into two groups, being stored for 2 and 48 hours. The following variables were evaluated: longitudinal (LD) and cross-sectional (CD) diameter, LD / CD ratio, fresh fruit mass (FM), pulp yield (PY), pH, soluble solids content (SS), titratable acidity (TA), SS / TA ratio, and ascorbic acid content (AA). Araçaúna fruits stand out due to their high PY (74.43\%), with low SS $\left(2.07^{\circ}\right.$ Brix $)$ and high TA (1.17\% citric acid). However, harvesting fully ripe fruits increases SS by $21 \%$ and reduces TA by $32.5 \%$. Grumixama fruits are slightly sweet $\left(6.06^{\circ} \mathrm{Brix}\right)$, with low acidity ( $0.39 \%$ citric acid), high vitamin C content (206.94 $\mathrm{mg}$ of ascorbic acid $/ 100 \mathrm{~g}$ of pulp), and harvest must be performed when fruits are fully ripe. Both species have pulp of potential quality to be commercially exploited, especially for processing.
\end{abstract}

Index terms: Psidium myrtoides O. Berg; Eugenia brasiliensis Lam.; native fruits; post-harvest storage.

\section{Qualidade físico-química de araçaúna e grumixama em diferentes estádios de maturação}

Corresponding author: moises.zucoloto@ufes.br

Received: May 17, 2020 Accepted: September 14, 2020

Copyright: All the contents of this journal, except where otherwise noted, is licensed under a Creative Commons Attribution License.

\section{(cc) $\mathbf{E Y}$}

Resumo- As características físico-químicas dos frutos de espécies nativas da Floresta Atlântica são pouco conhecidas, especialmente durante seu amadurecimento. O objetivo deste trabalho foi avaliar o efeito da interação entre o período de maturação e o armazenamento pós-colheita de araçaúna e grumixama. Os frutos foram colhidos em três estádios de maturação: verdes, parcialmente maduros e maduros, e separados em dois lotes, armazenados por 2 e 48 horas. Foram avaliados: diâmetro longitudinal (LD) e transversal (CD) dos frutos, relação LD/CD, massa fresca dos frutos (FM), rendimento em polpa (PY), $\mathrm{pH}$, sólidos solúveis (SS), acidez titulável (TA), ratio (SS/TA) e ácido ascórbico (AA). Os frutos de araçauneira destacaram-se por ter, em média, elevado PY $(74,43 \%)$, com baixo SS $\left(2,07^{\circ}\right.$ Brix) e alta TA $(1,17 \%$ de ácido cítrico). Porém, a colheita dos frutos totalmente maduros aumenta o SS em $21 \%$ e reduz a TA em 32,5\%, em comparação à média. Os frutos de grumixameira são levemente adocicados $\left(6,06^{\circ} \mathrm{Brix}\right)$, com baixa acidez $(0,39 \%$ de ácido cítrico), ricos em vitamina C (206,94 mg de ácido ascórbico/100 g de polpa), e sua colheita deve ser feita quando os frutos estiverem totalmente maduros. Ambas espécies possuem polpas de qualidade potencial para serem exploradas comercialmente em produtos processados.

Termos para indexação: Psidium myrtoides O. Berg; Eugenia brasiliensis Lam.; frutas nativas; armazenamento pós-colheita.

\footnotetext{
${ }^{1}$ M.Sc. in Tropical Agriculture, Researcher at Universidade Federal do Espírito Santo, São Mateus-ES, Brazil. Email: bruna_lara1@hotmail.com (ORCID 0000-0001-6787-566X)

${ }^{2} \mathrm{PhD}$ in Phytotechnics, Department of Agronomy, Professor at the Universidade Federal do Espírito Santo, Alegre - ES, Brazil. Email: moises. zucoloto@ufes.br (ORCID 0000-0003-0539-4750)

${ }^{3} \mathrm{PhD}$ in Genetics and Plant Breeding, Researcher at the Instituto Capixaba de Pesquisa, Assistência Técnica e Extensão Rural. Linhares - ES, Brazil. Email: sarah.moreira@incaper.es.gov.br (ORCID 0000-0003-0659-6725)

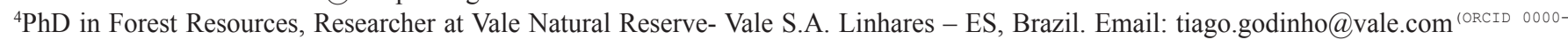
0001-6249-6054)

${ }^{5}$ M.Sc. in Tropical Agriculture, Researcher at Universidade Federal do Espírito Santo, São Mateus-ES, Brazil. Email: stanleybbuffon@gmail.com ${ }^{\text {(ORCID }}$ 0000-0002-9201-2695)

${ }^{6}$ M.Sc. in Tropical Agriculture, Researcher at Universidade Federal do Espírito Santo, São Mateus-ES, Brazil. Email: andreia-lopes02@ hotmail.com (ORCID 0000-0002-2767-5804)
} 


\section{Introduction}

The Atlantic Forest has high diversity of fruit species that are still consumed on a small scale due to the lack of knowledge by the general population. These fruits have characteristic and attractive color, flavor and aroma and, in some cases, stand out for their nutritional and antioxidant properties and high contents of phenolic compounds and carotenoids (SILVA et al., 2014; CASTELUCCI et al., 2020). Due to these characteristics, fruits native to the Atlantic Forest could be better used both for fresh consumption and in the food or pharmaceutical industry (DANNER et al., 2010; AGUIAR et al., 2016), becoming an option for commercial use and providing income diversification in rural properties.

Among these potential native fruits, araçaúna (Psidium myrtoides O. Berg) and grumixama (Eugenia brasiliensis Lam.), belonging to the Myrtaceae family, stand out. Araçaúna is a tree with height varying between 3 and 20 meters, has simple and leathery leaves, white flowers and purple and piriform or rounded fruits when ripe. Although native to the Atlantic Forest, occurring from restinga to mountain areas, araçaúna is also distributed in the Cerrado and Caatinga biomes (LORENZI et al., 2015; TULER et al., 2017). Grumixama, also known as grumixaba, cumbixaba, ibaporoiti and Brazilian cherry, is a tree with height varying between 8 and 15 meters, with leathery leaves and purple, red or yellow / white fruits. This species occurs mainly on the Brazilian coast from Santa Catarina to southern Bahia (LORENZI et al., 2015). However, it is found at $1,000 \mathrm{~m}$ above sea level in the state of Espírito Santo.

For these two species, recent reports are found in literature about their mineral composition, antioxidant capacity and antifungal activity (ZOLA et al., 2019; MACÊDO et al., 2020). However, they are punctual and do not cover the physicochemical characteristics of fruits, especially during ripening and post-harvest storage.

These studies are important, since the fruit ripening process and storage conditions change fruit size, yield and pulp quality, which can impact consumption and processing (DINIZ et al., 2017). In addition, Borges et al. (2010) pointed out that fruits of native species have interspecific variability in the duration of phenological stages that need to be known, so that criteria for harvesting and storage can be established. This can also be used for scaling production according to the needs of producer or industry. In view of the above, the aim of this work was to evaluate the effect of ripening stages and post-harvest storage on the physicochemical and morphological characteristics of araçaúna and grumixama.

\section{Material and methods}

Araçaúna and grumixama fruits were collected in the Orchard of Tropical Fruits of the Vale Natural Reserve, municipality of Linhares, Espírito Santo $\left(19^{\circ} 08^{\prime} 20.8^{\prime \prime} \mathrm{S}, 40^{\circ} 03^{\prime} 58.2^{\prime \prime} \mathrm{W}\right)$ and $35 \mathrm{~m}$ asl (Sisbio register No. 60674; SisGen register No. A019F83). The climate is classified as hot and humid tropical (Aw, according to the Köppen classification), with average annual temperature of $23.5^{\circ} \mathrm{C}$ and annual precipitation of 1,291 mm (ALVARES et al., 2013).

The chemical soil characterization in the $0-20 \mathrm{~cm}$ layer, according to Embrapa's soil analysis methodology (EMBRAPA, 2009) was: $\mathrm{pH}$ in water $=5.07$ (1: 2.5 ratio); phosphorus $=10.4 \mathrm{mg} / \mathrm{dm}^{3} ;$ potassium $=36 \mathrm{mg}$ $/ \mathrm{dm}^{3} ;$ sodium $=10 \mathrm{mg} / \mathrm{dm}^{3} ;$ calcium $=0.93 \mathrm{cmol}_{\mathrm{c}} /$ $\mathrm{dm}^{3} ;$ magnesium $=0.51 \mathrm{cmol}_{\mathrm{c}} / \mathrm{dm}^{3} ;$ aluminum $=0.95$ $\mathrm{cmol}_{\mathrm{c}} / \mathrm{dm}^{3} ; \mathrm{H}+\mathrm{Al}=5 \mathrm{cmol}_{\mathrm{c}} / \mathrm{dm}^{3}$; Sum of bases $=$ $1.57 \mathrm{cmol}_{\mathrm{c}} / \mathrm{dm}^{3}$; effective cation exchange capacity $=2.52 \mathrm{cmol}_{\mathrm{c}} / \mathrm{dm}^{3}$; base saturation index $=23.9 \%$; sodium saturation index $=1.73 \%$; organic matter $=1.88$ $\mathrm{dag} / \mathrm{dm}^{3}$. For phosphorus, potassium and sodium, the Mehlich-1 extractor was used; for calcium, magnesium and aluminum, $\mathrm{KCl}$ at concentration of $1 \mathrm{~mol} / \mathrm{L}$; and, for $\mathrm{H}+\mathrm{Al}$, SMP extractor.

Fruits were manually harvested from 20 mother plants of each species aged approximately 20 years, planted at a distance of $2 \times 3 \mathrm{~m}$ and in consortium with other native and exotic fruit species. There was no soil management, fertilization and irrigation in this area during the development of this study. Exsiccates were prepared and deposited at the Herbarium of the University Center of Northern Espírito Santo (Ceunes) - Federal University of Espírito Santo (Ufes). Deposit numbers were 8490 (Psidium myrtoides O. Berg) and 8500 (Eugenia brasiliensis Lam.).

The full flowering of plants and the number of days that elapsed between it and harvest at the different ripening stages were verified. For this, branches were marked in the median portion of the canopy, at the four cardinal points and weekly monitored. Full flowering was considered as the moment when marked branches had more than $70 \%$ of flowers open.

Fruits were collected between November and December 2017, when a change in the epicarp color was observed, and were divided into three ripening stages: 1) fully green fruits; 2) partially ripe fruits, with approximately $50 \%$ green epicarp; and, 3) fully ripe fruits (Figure 1). After harvesting, fruits were packed in polyethylene bags in thermal boxes with ice and transported to the Laboratory of Food Analysis of Ceunes for analysis. 

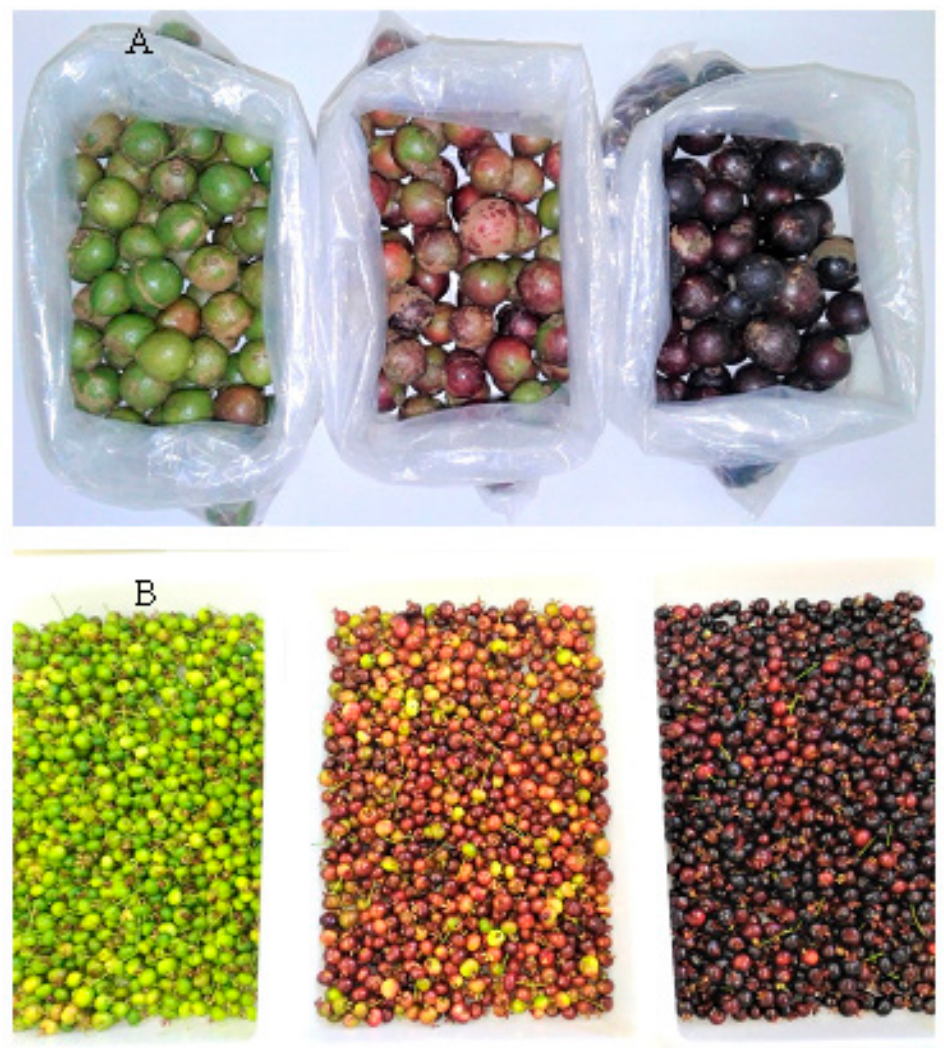

Figure 1. Araçaúna (Psidium myrtoides) (A) and grumixama (Eugenia brasiliensis) (B) fruits in the three ripening stages. E1: totally green fruits; E2: partially ripe fruits, with approximately $50 \%$ green epicarp; and, E3: fully ripe fruits.

To evaluate the maintenance of fruit quality during storage, fruits of each species and each ripening stage were separated into two groups. The first group was evaluated two hours after arriving at the laboratory, and the second group after 48 hours of storage. In these intervals, fruits were kept under ambient conditions, with air temperature between $24^{\circ} \mathrm{C}$ and $26^{\circ} \mathrm{C}$ and average relative humidity of $84.1 \%$.

For physical evaluations, eight araçaúna fruits and 40 grumixama fruits were randomly selected for each treatment, with four replicates. Longitudinal diameter (LD, mm); cross-sectional diameter (CD, $\mathrm{mm})$; LD / CD ratio; fresh fruit mass (FM, g); and pulp yield (PY, \%) were measured. Dimensions were valued with digital caliper and fresh mass was obtained by weighing whole fruits on a digital analytical scale. For PY, pulp mass was measured, considering fruits with skin and without seeds and, subsequently, the FM and pulp mass ratio was calculated.

For physicochemical analyses, $1.5 \mathrm{~kg}$ fruit samples per ripening stage and storage time were used, crushed and homogenized in multiprocessor and sieved to remove residues. Araçaúna fruits were fully processed and for grumixama fruits, seeds were removed. The following characteristics were evaluated: $\mathrm{pH}$ using digital bench $\mathrm{pH}$ meter; soluble solids content (SS, ${ }^{\circ} \mathrm{Brix}$ ) using digital refractometer; titratable acidity (TA, $\%$ of citric acid) determined by volumetry with phenolphthalein solution as indicator; SS / TA ratio given by dividing soluble solids content by the titratable acidity; and the ascorbic acid content (AA, mg of ascorbic acid / 100g of pulp), measured by titration based on the oxidation of ascorbic acid by potassium iodide. Analyses were performed, in triplicate for each repetition, according to the Analytical Standards of the Adolfo Lutz Institute (INSTITUTO ADOLFO LUTZ, 2008).

For each species, the experimental design was completely randomized in a $3 \times 2$ factorial scheme, with 3 ripening stages and 2 post-harvest storage times ( $2 \mathrm{~h}$ and $48 \mathrm{~h}$ ), with four replicates. Data homogeneity and normality was verified and, subsequently, they were submitted to analysis of variance and averages were compared by the Tukey test at 5\% probability. Analyses were performed with the aid of the Genes statistical software (CRUZ, 2016). 


\section{Results and discussion}

In araçaúna plants, full flowering occurred between 15 and 30 September 2017. Fruits at ripening stage 1 (E1) were harvested 46 days after full flowering (DAF); and fruits at stages 2 and 3 (E2 and E3, respectively) at 98 DAF. In grumixama fruits, full flowering occurred between 16 and 21 November 2017. Fruits at E1 were harvested 18 DAF and fruits at E2 and E3, only at 28 DAF. For both species, the proportion of fruits at E2 and E3 at the time of collection was not evaluated, which could be used to define harvest strategies.

Both for araçaúna and grumixama, there were fruits at $E 2$ and $E 3$ in the same branch, allowing harvesting on the same day, showing the uneven maturation of fruits for these species, which was also observed by Borges et al. (2010). This indicates the need for studies on the management of cultural treatments of these species, especially pruning, which can improve fruit maturation uniformity, favoring harvest and reducing production costs. On the other hand, harvest unevenness can be used by producers as a way of staggering production, or to offer the market fruits outside the season of greatest supply.

\section{Araçaúna (Psidium myrtoides O. Berg)}

For araçaúna, there was interaction between ripening stages and post-harvest evaluation times for LD, CD, FM and SS / TA. On the other hand, except for PY, all variables evaluated were affected by at least one of the factors individually (Table 1).

The highest $\mathrm{CD}$ and $\mathrm{LD}$ values were obtained at $\mathrm{E} 3$, and in evaluation performed $2 \mathrm{~h}$ after harvest, these values did not differ from E1, and $48 \mathrm{~h}$ after harvest, from E2, justifying the interaction between these factors (Table 2). Increase in fruit size after harvest observed for E2 considering LD, and E2 and E3 considering CD, may be related to the destruction of internal tissues of the pericarp wall in favor of seed development. Another factor that may have contributed to this was the lack of fruit standardization before storage, despite the sample used is random.

Araçaúna fruits have similar longitudinal and cross-sectional diameters, resulting in average LD / CD ratio of 1.01, indicating rounded fruits, which favors the use by industry for facilitating processing operations. For this variable, there was reduction in the value obtained only in the evaluation of fruits at E2 and $48 \mathrm{~h}$ after harvest, since the evolution of $\mathrm{LD}$ and $\mathrm{CD}$ values had proportional behavior (Table 2).

Table 1. Summary of analysis of variance for longitudinal diameter (LD); cross-sectional diameter (CD); LD / CD ratio; fruit mass (FM); pulp yield (PY); $\mathrm{pH}$; soluble solids content (SS); titratable acidity (TA); and, SS / TA ratio of araçaúna fruits (Psidium mytroides) in three ripening stages and two storage times after harvest.

\begin{tabular}{cccccccccc}
\hline & \multicolumn{10}{c}{ Medium Squares } \\
\hline VF & LD & CD & LD / CD & FM & PY & pH & SS & TA & SS / TA \\
Storage times & $1.10^{*}$ & $3.99^{*}$ & $4.00^{*}$ & $0.15^{\text {ns }}$ & $256.98^{\text {ns }}$ & $0.14^{*}$ & $0.03^{\text {ns }}$ & $0.02^{\text {ns }}$ & $1.38^{\text {ns }}$ \\
Ripening stages & $0.65^{*}$ & $0.54^{*}$ & $0.02^{\text {ns }}$ & $0.59^{*}$ & $18.21^{\text {ns }}$ & $0.20^{*}$ & $1.20^{*}$ & $1.00^{*}$ & $10.88^{*}$ \\
Interaction & $1.33^{*}$ & $2.08^{*}$ & $0.40^{\text {ns }}$ & $0.22^{*}$ & $165.40^{\text {ns }}$ & $0.03^{\text {ns }}$ & $0.19^{\text {ns }}$ & $0.08^{\text {ns }}$ & $4.52^{*}$ \\
Residue & 0.17 & 0.11 & 0.66 & 0.06 & 137.79 & 0.03 & 0.12 & 0.05 & 0.67 \\
\hline
\end{tabular}

ns, *: Not significant and significant at $5 \%$ probability by the $\mathrm{F}$ test.

For FM, the highest averages were obtained at $\mathrm{E} 1$ and $\mathrm{E} 3$ in evaluation performed $2 \mathrm{~h}$ after harvest; and for E2 and E3 in evaluation performed 48h after harvest. In addition, storage only caused loss of FM at E1 (Table 2). For this reason, the most recommended is to harvest araçaúna in the ripe stage, which will allow associating the harvest of heavier fruits and the possibility of storage for 48 hours. It is noteworthy that, while LD at E2 and
$\mathrm{CD}$ at E2 and E3 were favored by storage, as previously mentioned, the same is not true for FM. According to Esemann-Quadros et al. (2008), the final stage of fruit development is determined by the end of cell division and beginning of cell expansion until its final size, with consequent increase in cell volume. This could have altered fruit density after harvest, justifying an increase in the size of araçaúna without changing its mass. 
Table 2. Comparison between means and coefficient of variation (CV, in \%) of longitudinal diameter (LD); crosssectional diameter (CD); LD / CD ratio; fruit mass (FM); pulp yield (PY); $\mathrm{pH}$; soluble solids content (SS); titratable acidity (TA); and SS / TA ratio of araçaúna fruits (Psidium mytroides) in three ripening stages and two storage times after harvest.

\begin{tabular}{|c|c|c|c|c|c|c|}
\hline \multirow{2}{*}{ Stage } & \multicolumn{2}{|c|}{$\mathrm{LD}(\mathrm{mm})$} & \multicolumn{2}{|c|}{$\mathrm{CD}(\mathrm{mm})$} & \multicolumn{2}{|c|}{$\mathrm{LD} / \mathrm{CD}$} \\
\hline & $2 \mathrm{~h}$ & $48 \mathrm{~h}$ & $2 \mathrm{~h}$ & $48 \mathrm{~h}$ & $2 \mathrm{~h}$ & $48 \mathrm{~h}$ \\
\hline 1 & $15.60 \mathrm{ABa}$ & $15.24 \mathrm{Ba}$ & $15.31 \mathrm{Aa}$ & $15.11 \mathrm{Ba}$ & $1.02 \mathrm{Aa}$ & $1.01 \mathrm{Aa}$ \\
\hline 2 & $14.98 \mathrm{Bb}$ & $16.25 \mathrm{Aa}$ & $14.51 \mathrm{Bb}$ & $16.36 \mathrm{Aa}$ & $1.03 \mathrm{Aa}$ & $0.99 \mathrm{Ab}$ \\
\hline 3 & $15.80 \mathrm{Aa}$ & $16.17 \mathrm{Aa}$ & $15.33 \mathrm{Ab}$ & $16.13 \mathrm{Aa}$ & $1.03 \mathrm{Aa}$ & $1.00 \mathrm{Aa}$ \\
\hline Mean & \multicolumn{2}{|c|}{15.67} & \multicolumn{2}{|c|}{15.46} & \multicolumn{2}{|c|}{1.01} \\
\hline $\mathrm{CV}$ & \multicolumn{2}{|c|}{2.67} & \multicolumn{2}{|c|}{2.17} & \multicolumn{2}{|c|}{2.53} \\
\hline \multirow{2}{*}{ Stage } & \multicolumn{2}{|c|}{ FM $(g)$} & \multicolumn{2}{|c|}{ PY (\%) } & \multicolumn{2}{|c|}{$\mathrm{pH}$} \\
\hline & $2 \mathrm{~h}$ & $48 \mathrm{~h}$ & $2 \mathrm{~h}$ & $48 \mathrm{~h}$ & $2 \mathrm{~h}$ & $48 \mathrm{~h}$ \\
\hline 1 & $2.60 \mathrm{ABa}$ & $2.07 \mathrm{Bb}$ & $73.04 \mathrm{Aa}$ & $76.45 \mathrm{Aa}$ & $3.47 \mathrm{Aa}$ & $3.20 \mathrm{Ab}$ \\
\hline 2 & $2.40 \mathrm{Ba}$ & $2.48 \mathrm{ABa}$ & 82.96Aa & $68.55 \mathrm{Aa}$ & $3.03 \mathrm{Ba}$ & $3.02 \mathrm{Aa}$ \\
\hline 3 & $2.85 \mathrm{Aa}$ & $2.85 \mathrm{Aa}$ & $77.10 \mathrm{Aa}$ & $68.47 \mathrm{Aa}$ & $3.22 \mathrm{ABa}$ & $3.05 \mathrm{Aa}$ \\
\hline Mean & \multicolumn{2}{|c|}{2.54} & \multicolumn{2}{|c|}{74.43} & \multicolumn{2}{|c|}{3.17} \\
\hline $\mathrm{CV}$ & \multicolumn{2}{|c|}{9.61} & \multicolumn{2}{|c|}{15.77} & \multicolumn{2}{|c|}{5.25} \\
\hline \multirow{2}{*}{ Stage } & \multicolumn{2}{|c|}{ SS $\left({ }^{\circ}\right.$ Brix $)$} & \multicolumn{2}{|c|}{ TA $(\%)$} & \multicolumn{2}{|c|}{$\mathrm{SS} / \mathrm{TA}$} \\
\hline & $2 \mathrm{~h}$ & $48 \mathrm{~h}$ & $2 \mathrm{~h}$ & $48 \mathrm{~h}$ & $2 \mathrm{~h}$ & $48 \mathrm{~h}$ \\
\hline 1 & $1.77 \mathrm{Ba}$ & $1.80 \mathrm{Aa}$ & $1.23 \mathrm{Aa}$ & $1.22 \mathrm{ABa}$ & $1.44 \mathrm{Ba}$ & $1.51 \mathrm{Ba}$ \\
\hline 2 & $1.82 \mathrm{Ba}$ & $2.00 \mathrm{Aa}$ & $1.54 \mathrm{Aa}$ & $1.44 \mathrm{Aa}$ & $1.20 \mathrm{Ba}$ & $1.39 \mathrm{Ba}$ \\
\hline 3 & $2.72 \mathrm{Aa}$ & $2.30 \mathrm{Aa}$ & $0.65 \mathrm{Ba}$ & $0.93 \mathrm{Ba}$ & $4.25 \mathrm{Aa}$ & $2.55 \mathrm{Ab}$ \\
\hline Mean & \multicolumn{2}{|c|}{2.07} & \multicolumn{2}{|c|}{1.17} & \multicolumn{2}{|c|}{2.05} \\
\hline $\mathrm{CV}$ & \multicolumn{2}{|c|}{17.04} & \multicolumn{2}{|c|}{19.91} & \multicolumn{2}{|c|}{39.97} \\
\hline
\end{tabular}

Means followed by the same uppercase letter in column and lowercase in row do not differ significantly with $5 \%$ error probability by the Tukey test.

As for pulp yield (PY), araçaúna was not influenced by fruit ripening stages or post-harvest storage times (Table 1). The average value obtained was $74.43 \%$, which is favorable for both fresh consumption and processing, as it provides raw material for making different preparations and few residues (Table 2). For guava (P. guajava), which is the main commercial species of the genus, with commercial cultivars developed and with extensively studied fertilization, pruning and irrigation management, Campos et al. (2016) observed yield values between 79.56 to $80.56 \%$. This reinforces the commercial potential of araçaúna, which can be considered a semi-domesticated species, as fruits are consumed by humans, but with few improvement and management studies.

Fruits at E1 and E3 had higher $\mathrm{pH}$ values in evaluation performed $2 \mathrm{~h}$ after harvest and did not differ from each other after $48 \mathrm{~h}$ of storage. For E2 and E3, storage did not change $\mathrm{pH}$ value (Table2). According to Alvarenga et al. (2014), variation in $\mathrm{pH}$ during ripening indicates the presence of few buffering substances, such as mineral salts and pectin, which may explain the reduction in $\mathrm{pH}$ at $\mathrm{E} 1$ over the storage time. The harvest of the ripest fruits at E2 and E3 favored pH stability.

The soluble solids content (SS) varied only for evaluation performed $2 \mathrm{~h}$ after harvest, where fruits harvested at E3 had greater value. For TA, the opposite was observed, when fruits at E3 evaluated $2 \mathrm{~h}$ after harvest had lower value. In addition, for TA evaluated $48 \mathrm{~h}$ after harvest, E1 did not differ from E3. For both SS and TA, storage for 48 hours did not cause changes, regardless of fruit ripening stage. For the SS / TA ratio, fruits harvested at E3 had higher value; however, with significant losses during storage (Table 2). Due to this combination of results, it was observed that the harvest of fully ripe fruits is the best strategy, as it provides better sensory quality (greater sweetness and lower acidity), which was also observed by Drehmer and Amarante (2008) for 'araçá-vermelho' (P. cattleianum). 
Araçaúna fruits had low soluble solids content (average of $2.07^{\circ}$ Brix) and high acidity (average of $1.17 \%$ citric acid), which limits their consumption in the Brazilian market (Table 2). Although there is no established limit for this species, the quality standard for fruit juices and pulps in Brazil, defined by the Ministry of Agriculture, determines minimum soluble solids value of $4.5^{\circ}$ Brix for araçá (P. cattleianum) and $7^{\circ}$ Brix for guava (P. guajava) (BRASIL, 2018). For araçá (P. cattleianum), Medina et al. (2011) reported SS between 6 and $11.8^{\circ}$ Brix and TA between 7.30 and $16.19 \%$ of citric acid, and Drehmer and Amarante (2008) observed SS between 10 and $12{ }^{\circ}$ Brix and TA between 2 and $3.5 \%$ of citric acid. Therefore, the use of araçaúna is recommended for the preparation of jams, sweets and ice creams, which can boost its cultivation.

Due to the difficulty of obtaining araçaúna pulp sample volume, it was not possible to quantify the ascorbic acid content at E1 and E2. At E3 and $2 \mathrm{~h}$ after harvest, $248.28 \mathrm{mg}$ of ascorbic acid / 100g of pulp was observed, which is why it is considered an excellent source of vitamin $C$, exceeding other traditional tropical fruits, such as guava (85.9 mg AA / 100g of pulp), 'Formosa' papaya ( $80.2 \mathrm{mg} \mathrm{AA} / 100 \mathrm{~g}$ of pulp) and 'Tommy' mango (17.5 mg AA / 100g of pulp) (OLIVEIRA et al., 2011).

\section{Grumixama (Eugenia brasiliensis Lam.)}

Among the physical evaluations of grumixama, interaction between ripening stages and post-harvest times was observed only for the LD / CD ratio and for the pulp yield (PY). For LD, CD and FM, differences were observed only among ripening stages, pointing out that storage for up to 48 hours did not interfere in these variables. For chemical analyses, lack of interaction was only observed for the soluble solids content (SS), although the factors studied were significant in isolation (Table 3). This result indicates that chemical variables were most affected by the ripening process and storage. Therefore, it is necessary to evaluate $\mathrm{pH}$ and acidity before supplying ripe and stored grumixama fruits to the market, even if they have satisfactory appearance.
For $\mathrm{LD}$, the highest values were observed for E3 in evaluation performed 2 hours after storage; and for E2 and E3 when evaluation was performed after 48 hours. For $\mathrm{CD}$, the opposite was observed: E2 and E3 were equal $2 \mathrm{~h}$ after harvest and E3 was higher after $48 \mathrm{~h}$ of storage. The LD / CD ratio followed the same behavior as $\mathrm{LD}$, except for the reduction caused by storage for 48 hours at E3. As grumixama shifted from E1 to E3, there was an average gain of $12.5 \%$ for $\mathrm{LD}$ and $6.6 \%$ for CD. This difference in increments along ripening favored the interaction observed for the LD / CD ratio. In addition, the $\mathrm{LD} / \mathrm{CD}$ ratio characterizes grumixama as slightly flat $(\mathrm{LD} / \mathrm{CD}<1)($ Table 4).

For fruit mass (FM), the highest averages were found for E3 (Table 4). These results indicate that when harvested fully ripe, grumixama is larger and heavier. Silva et al. (2017) worked with cagaita (E. dysenterica) and observed that the highest fruit mass was obtained with ripe fruits and Diniz et al. (2017) observed an increase in mass and in longitudinal and cross-sectional diameters during the ripening of camu-camu fruits $(E$. cibrata). Both authors stressed that this is due to the expansion of cell walls, which reaches its maximum value in ripe fruits.

In contrast to what was observed with the other physical variables, storage for 48 hours promoted significant losses in grumixama pulp yield (PY), regardless of ripening stages. For E3, PY decreased by more than $31 \%$ after storage for 48 hours (Table 4). In addition to yield loss, grumixama skin darkened during storage, which interferes with its visual quality. Due to its perishability, the commercial use of fresh grumixama is not feasible until alternatives are established to extend its shelf life.

Table 3. Summary of analysis of variance for longitudinal diameter (LD); cross-sectional diameter (CD); LD / CD ratio; fruit mass (FM); pulp yield (PY); $\mathrm{pH}$; soluble solids content (SS); titratable acidity (TA); $\mathrm{SS} / \mathrm{TA}$ ratio; and ascorbic acid content (AA) of grumixama fruits (Eugenia brasiliensis) in three ripening stages and two storage times after harvest.

\begin{tabular}{lccccccccccc}
\hline & \multicolumn{11}{c}{ Medium Squares } \\
\hline VF & LD & CD & LD / CD & FM & PY & pH & SS & TA & SS / TA & AA \\
Storage times & $0.05^{\text {ns }}$ & $0.07^{\text {ns }}$ & $0.60^{*}$ & $0.01^{\text {ns }}$ & $1135.1^{*}$ & $0.01^{\text {ns }}$ & $0.68^{*}$ & $0.22^{*}$ & $92.08^{*}$ & $47.56^{*}$ \\
Ripening stages & $5.89^{*}$ & $2.87^{*}$ & $4.75^{*}$ & $0.96^{*}$ & $90.13^{*}$ & $0.30^{*}$ & $4.95^{*}$ & $0.03^{\text {ns }}$ & $67.42^{*}$ & $44.63^{*}$ \\
Interaction & $0.24^{\text {ns }}$ & $0.21^{\text {ns }}$ & $0.54^{*}$ & $0.08^{\text {ns }}$ & $149.41^{*}$ & $0.13^{*}$ & $0.21^{\text {ns }}$ & $0.27^{*}$ & $58.68^{*}$ & $31.37^{*}$ \\
Residue & 0.12 & 0.23 & 0.08 & 0.04 & 10.22 & 0.02 & 0.06 & 0.02 & 6.33 & 3.96 \\
\hline
\end{tabular}

$\mathrm{ns}, *$ : Not significant and significant at $5 \%$ probability by the $\mathrm{F}$ test. 
Table 4. Comparison between means and coefficient of variation (CV, in \%) of longitudinal diameter (LD); crosssectional diameter (CD); LD / CD ratio; fruit mass (FM); pulp yield (PY); $\mathrm{pH}$. soluble solids content (SS); titratable acidity (TA); SS / TA ratio; and ascorbic acid content (AA) of grumixama fruits (Eugenia brasiliensis) in three ripening stages and two storage times after harvest.

\begin{tabular}{|c|c|c|c|c|c|c|c|c|c|c|}
\hline \multirow{2}{*}{ Stage } & \multicolumn{2}{|c|}{$\mathrm{LD}(\mathrm{mm})$} & \multicolumn{2}{|c|}{$\mathrm{CD}(\mathrm{mm})$} & \multicolumn{2}{|c|}{$\mathrm{LD} / \mathrm{CD}$} & \multicolumn{2}{|c|}{$\mathrm{FM}(\mathrm{g})$} & \multicolumn{2}{|c|}{ PY (\%) } \\
\hline & $2 \mathrm{~h}$ & $48 \mathrm{~h}$ & $2 \mathrm{~h}$ & $48 \mathrm{~h}$ & $2 \mathrm{~h}$ & $48 \mathrm{~h}$ & $2 \mathrm{~h}$ & $48 \mathrm{~h}$ & $2 \mathrm{~h}$ & $48 \mathrm{~h}$ \\
\hline 1 & $13.50 \mathrm{Ca}$ & $13.74 \mathrm{Ba}$ & $17.66 \mathrm{Ba}$ & $18.10 \mathrm{Ba}$ & $0.76 \mathrm{Ca}$ & $0.76 \mathrm{Ba}$ & $2.59 \mathrm{Ca}$ & $2.86 \mathrm{Ba}$ & $73.62 \mathrm{Aa}$ & $62.13 \mathrm{Ab}$ \\
\hline 2 & $14.67 \mathrm{Ba}$ & $14.61 \mathrm{Aa}$ & $18.39 \mathrm{ABa}$ & 18.19Ba & $0.80 \mathrm{Ba}$ & $0.80 \mathrm{Aa}$ & $3.03 \mathrm{Ba}$ & $2.95 \mathrm{Ba}$ & 72.67Aa & $66.20 \mathrm{Ab}$ \\
\hline 3 & $15.55 \mathrm{Aa}$ & $15.09 \mathrm{Aa}$ & $19.02 \mathrm{Aa}$ & $19.11 \mathrm{Aa}$ & $0.82 \mathrm{Aa}$ & $0.79 \mathrm{Ab}$ & $3.45 \mathrm{Aa}$ & $3.37 \mathrm{Aa}$ & $74.66 \mathrm{Aa}$ & $51.35 \mathrm{Bb}$ \\
\hline Mean & & 4.53 & 18 & 41 & 0.7 & & 3. & 04 & & 6.77 \\
\hline $\mathrm{CV}$ & & .37 & 2. & 61 & 1.1 & & 6. & 55 & & .79 \\
\hline \multirow{2}{*}{ Stage } & \multicolumn{2}{|c|}{$\mathrm{pH}$} & \multicolumn{2}{|c|}{$\mathrm{SS}\left({ }^{\circ}\right.$ Brix $)$} & \multicolumn{2}{|c|}{ TA $(\%)$} & \multicolumn{2}{|c|}{$\mathrm{SS} / \mathrm{TA}$} & \multicolumn{2}{|c|}{$\begin{array}{l}\text { AA (mg of ascorbic } \\
\text { acid } / 100 \mathrm{~g} \text { of pulp) }\end{array}$} \\
\hline & $2 \mathrm{~h}$ & $48 \mathrm{~h}$ & $2 \mathrm{~h}$ & $48 \mathrm{~h}$ & $2 \mathrm{~h}$ & $48 \mathrm{~h}$ & $2 \mathrm{~h}$ & $48 \mathrm{~h}$ & $2 \mathrm{~h}$ & $48 \mathrm{~h}$ \\
\hline 1 & $3.84 \mathrm{Aa}$ & $3.83 \mathrm{Aa}$ & $5.16 \mathrm{Ca}$ & $5.22 \mathrm{Ba}$ & $0.36 \mathrm{Bb}$ & $0.43 \mathrm{Aa}$ & $14.50 \mathrm{Aa}$ & $12.17 \mathrm{Ba}$ & $221.34 \mathrm{Ba}$ & $69.03 \mathrm{Bb}$ \\
\hline 2 & $3.67 \mathrm{Bb}$ & $3.77 \mathrm{ABa}$ & $5.89 \mathrm{Bb}$ & $6.58 \mathrm{Aa}$ & $0.47 \mathrm{Aa}$ & $0.34 \mathrm{Bb}$ & $12.46 \mathrm{Ab}$ & $19.35 \mathrm{Aa}$ & $158.05 \mathrm{Ba}$ & 213.27Aa \\
\hline 3 & $3.77 \mathrm{Aa}$ & $3.71 \mathrm{Ba}$ & $6.61 \mathrm{Aa}$ & $6.87 \mathrm{Aa}$ & $0.43 \mathrm{ABa}$ & $0.31 \mathrm{Bb}$ & $15.53 \mathrm{Ab}$ & $22.73 \mathrm{Aa}$ & $374.96 \mathrm{Aa}$ & $204.95 \mathrm{Ab}$ \\
\hline Mean & \multicolumn{2}{|c|}{3.76} & \multicolumn{2}{|c|}{6.06} & \multicolumn{2}{|c|}{0.39} & \multicolumn{2}{|c|}{16.12} & \multicolumn{2}{|c|}{206.94} \\
\hline $\mathrm{CV}$ & \multicolumn{2}{|c|}{1.27} & \multicolumn{2}{|c|}{4.01} & \multicolumn{2}{|c|}{11.69} & \multicolumn{2}{|c|}{15.61} & \multicolumn{2}{|c|}{30.42} \\
\hline
\end{tabular}

Means followed by the same uppercase letter in column and lowercase in row do not differ significantly with 5\% error probability by the Tukey test.

On the other hand, the high pulp yield (PY) obtained $2 \mathrm{~h}$ after harvest, with values higher than $72 \%$, shows the potential of this species for processing. This value was close to that of other species popularly referred to as cherry trees, such as camu-camu (E. cibrata, $72.1 \pm$ 4.88\%) (DINIZ et al., 2017); pitangueira-do-cerrado ( $E$. calycina, 59.1\%) (BORGES et al., 2010) and pitanga ( $E$. uniflora, 79.46\%) (BATISTA et al., 2014). In addition to the high yield, Aguiar et al. (2016) observed that grumixama jelly had acceptability and purchase intention above $83 \%$, which is why it is an underestimated way of using fruits. Finally, Zola et al. (2019) highlighted the antioxidant and antimicrobial potential of grumixama that can be used as a promising natural agent for future applications in the food and pharmaceutical industry.

The $\mathrm{pH}$ behavior of grumixama was not linear, both in relation to the ripening stage and storage time. In evaluation performed $2 \mathrm{~h}$ after harvest, $\mathrm{pH}$ was lower at E2. After $48 \mathrm{~h}$ of storage, E2 did not differ from E3. For $\mathrm{E} 1$ and $\mathrm{E}$ 3, fruit storage did not change $\mathrm{pH}$; for $\mathrm{E} 2, \mathrm{pH}$ was higher after storage. The low coefficient of variation favored the differences found, although the interval between the highest and lowest $\mathrm{pH}$ value was only 0.17 (4.6\%) (Table 4).

The soluble solids content (SS) was higher at E3, when fruits were evaluated $2 \mathrm{~h}$ after harvest, and after 48h, E3 was not different from E2. Only for E2, storage for 48 hours caused an increase in SS (Table 4). The harvest of fully ripe fruits provided an average increase of $1.55^{\circ}$ Brix (29.9\%), and should therefore be prioritized. The SS values obtained ranged from 5.16 to $6.87^{\circ}$ Brix, close to those observed by Zola et al. (2019) (5.0 ${ }^{\circ}$ Brix), but lower than those reported by Silva et al. (2014) (9.4 ${ }^{\circ}$ Brix) for the same species. According to Fabi et al. (2010), places of cultivation, fertilization, irrigation and genetic material can interfere in the proximate composition of fruits.

Storage for 48 hours caused an increase in titratable acidity (TA) of fruits harvested at E1; however, for fruits harvested at E2 and E3, the opposite was observed (Table 4). Evaluating different fruits native to the state of Ceará, Gonçalves et al. (2017) observed that acidity had different behavior during ripening, not being possible to establish a single harvest pattern. For grumixama, Aguiar et al. (2016) observed TA of 0.29\% citric acid, close to value observed in this study.

For the SS / TA ratio, there were no differences among ripening stages for evaluation performed $2 \mathrm{~h}$ after harvest. However, storage for 48 hours favored the SS / TA ratio for fruits harvested at E2 and E3, both in relation to those obtained at E1 and in relation to those evaluated $2 \mathrm{~h}$ after harvest (Table 4). For this variable and considering the results observed for SS, TA and PY, grumixama must be harvested ripe; however, to be stored, it is necessary to establish methodology that allows maintaining fruit quality, especially skin color and yield. 
This harvesting strategy will also favor the ascorbic acid content of grumixama fruits (AA), since those harvested at E3 had higher value, both in relation to the other ripening stages evaluated $2 \mathrm{~h}$ after harvest, and in relation to fruits stored for 48 hours, which did not differ from those at E2 (Table 4). Grumixama fruits had, on average, $206 \mathrm{mg}$ of ascorbic acid / 100g of pulp, greater than values observed for other fruits native to the Cerrado, such as cagaita (E. dysenterica: 10.63), cajuzinho-do-cerrado (Anacardium othonianum: 5.48) and gabiroba (Campomanesia adamantium: 61.49) (ALVES et al., 2017); to the Amazon such as bacuri (Platonia insigni: 75.04); cupuaçu (Theobroma grandiflorum: 54.23); murici (Byrsonima crassifolia: 108.67) (SANTOS et al. 2019); and to the Atlantic Forest such as cambuci (Campomanesia phaea: 3.16), feijoa (Feijoa sellowiana: 3.16), uvaia (E. pyriformis: 85.40) (CASTELUCCI et al., 2020), all in mg ascorbic acid/ $100 \mathrm{~g}$ of pulp. This reinforces grumixama as an excellent source of vitamin $\mathrm{C}$ still little known by the general population.

\section{Conclusion}

Araçaúna and grumixama have pulp of potential quality to be commercially exploited, especially for processing, due to the rapid loss of quality after harvest.

The ripening stage and the storage period alter the physicochemical characteristics of araçaúna and grumixama fruits. Therefore, fruits of both species must be harvested fully ripe and techniques to increase their shelf life after harvest need to be developed.

\section{Acknowledgments}

To the Coordination for the Improvement of Higher Education Personnel (Capes - financing code 001), to the Espírito Santo Research and Innovation Support Foundation (Fapes) and Vale Natural Reserve.

\section{References}

AGUIAR, T.M. de; SABAA-SRUR, A.U.O.; SMITH, R.E.Study of grumixama (Eugenia brasiliensis Lam) fruit pulp and development of a jelly: rheological, sensorial and colorimetric evaluation. The Natural Products Journal, Washington, v.6, n.2, p.142-151, 2016.
AlVARENGA, C.A.G.; PASSAGLiA, K.A.; CIABOTTI, S.; JESUS, E.de J.; PERINI, T.F. Avaliação da fruta de Eugenia uvalha Cambes sob estádios de desenvolvimento. Global Science and Technology, Rio Verde, v.7, n.1, p.67-75, 2014.

ALVARES, C.A.; STAPE, J.L.; SENTELHAS, P.C.; GOLÇALVES, J.L.M.; SPAVOREK, G.Köppen's climate classification map for Brazil. Meteorologische Zeitschrift, Stuttgart, v.22, n.6, p.711-728, 2013.

ALVES, A.M.; DIAS, T.; HASSIMOTTO, N.M.A.; NAVES, M.M.V. Ascorbic acid and phenolic contents, antioxidant capacity and flavonoids composition of Brazilian Savannah native fruits. Food Science and Technology, Campinas, v.37, n.4, p.564-569, 2017.

BATISTA, A.D.; FONSECA, A.A.O.; COSTA, M.A.P. de C.; BITTENCOURT, N.S. Caracterização física, físico-química e química de frutos de pitangueiras oriundas de cinco municípios baianos. Magistra, Cruz das Almas, v.26, n.3, p.393- 402, 2014.

BORGES, K.C. de F.; SANTANA, D.G. de; MELO, B. de; SANTOS, C.M. dos. Rendimento de polpa e morfometria de frutos e sementes de pitangueirado-cerrado. Revista Brasileira de Fruticultura, Jaboticabal, v.32, n.2, p.471-478, 2010.

BRASIL, Instrução Normativa $\mathrm{N}^{\mathrm{o}} 37$ Secretaria de Defesa Agropecuária. Diário Oficial [da] República Federativa do Brasil, Brasília, DF, v.155, n. 194, 8 out. 2018. Seção 1, p.23-33. Disponível em: http://www. in.gov.br/materia/-/asset publisher/Kujrw0TZC2Mb/ content/id/44304943/do1-2018-10-08-instrucaonormativa-n-37-de-1-de-outubro-de-2018-44304612. Acesso em: 31 jan. 2019.

CAMPOS, B.M.; VIANA, A.P.; QUINTAL, S.S.R.; BARBOSA, C.D.; DAHER, R.F. Heterotic group formation in Psidium guajava L. by artificial neural network and discriminant analysis. Revista Brasileira de Fruticultura, Jaboticabal, v.38, n.1, p.151-157, 2016.

CASTELUCCI, A.C.L.; SILVA, P.P.M. da; SPOTO, M.H.F. Bioactive compounds and in vitro antioxidant activity of pulps from fruits from the Brazilian atlantic forest. Acta Scientiarum Technology, Maringá, v.42, e44503, 2020. 
CRUZ, C.D. Genes Software - extended and integrated with the R, Matlab and Selegen. Acta Scientiarum Agronomy, Maringá, v.38, n.4, p.547-552, 2016.

DANNER, M.A.; CITADIN, I.; SASSO, S.A.Z.; SACHET, M.R.; AMBROSIO, R. Fenologia da floração e frutificação de mirtáceas nativas da floresta com araucária. Revista Brasileira de Fruticultura, Jaboticabal, v.32, n.1, p.291-295, 2010.

DINIZ, G.A.S.; ARAÚJO NETO, S.E.; NOVELLI, D. da S.; NOGUEIRA, N.T.; SILVA, I.F. da. Quality index and harvest maturity of Eugenia cibrata fruits. Revista Brasileira de Fruticultura, Jaboticabal, v.39, n.esp, p.1-8, 2017.

DREHMER,A.M.F.;AMARANTE, C.V.T. Conservação pós-colheita de frutos de araçá-vermelho em função do estádio de maturação e temperatura de armazenamento. Revista Brasileira de Fruticultura, Jaboticabal, v.30, n.2, p.322-326, 2008.

EMBRAPA. Empresa Brasileira de Pesquisa Agropecuária. Manual de análises químicas de solos, plantas e fertilizantes. 2.ed. Brasília: Embrapa Informação Tecnológica, 2009. 627p.

ESEMANN-QUADROS, K.; MOTA, A.P.; KERBAUY, G B.; GUERRA, M.P.; DUCROQUET, J.P.H.J.; PESCADOR, R. Estudo anatômico do crescimento do fruto em Acca sellowiana Berg. Revista Brasileira de Fruticultura, Jaboticabal, v.30, n.2, p.296-302, 2008.

FABI, J.P.; PERONI, F.H.G.; GOMEZ, M.L.P.A. Papaya, mango and guava fruit metabolism during ripening: postharvest changes affecting tropical fruit nutritional content and quality. Fresh Produce, Pretoria, v.4, p.56-66, 2010.

GONÇALVES, N.P.; LUCENA, E.M.P.de; BONILLA, O.H.; TAVARES, F.J.C. Physico-chemical composition of native fruits of the Ceará coast at different development stages. Revista Brasileira de Engenharia Agrícola e Ambiental, Campina Grande, v.21, n.9, p.640-644, 2017.

INSTITUTO ADOLFO LUTZ. Métodos físicoquímicos para análise de alimentos. 5.ed. São Paulo: Instituto Adolfo Lutz, 2008. p.1020.
LORENZI, H.; LACERDA, M.T.C. de; BACHER, L.B. Frutas no Brasil nativas e exóticas: de consumo in natura. São Paulo: Instituto Plantarum de Estudos da Flora, 2015. 768 p.

MACÊDO, D.G. de; SOUZA, M.M. de A.; MORAISBRAGA, M.F.B.; COUTINHO, H.D.M.; SANTOS, A.T.L. dos; MACHADO, A.J.T.; RODRIGUES, F.F.G.; COSTA, J.G.M. da; MENEZES, I.R.A.de. Seasonality influence on the chemical composition and antifungal activity of Psidium myrtoides O. Berg. South African Journal of Botany, KwaZulu-Natal, v.128, p.9-17, 2020.

MEDINA, A.L.; HAAS, L.I.R.; CHAVES, F.C.; SALVADOR, M.; ZAMBIAZI, R.C.; SILVA, W.P. da; ROMBALDI, C.V. Araçá (Psidium cattleianum Sabine) fruit extracts with antioxidant and antimicrobial activities and antiproliferative effect on human cancer cells. Food Chemistry, Londres, v.128, n.4, p.916922, 2011.

OLIVEIRA, D. da S.;AQUINO, P.P.; RIBEIRO, M.R.R.; PROENÇA, R. da C.P.; PINHEIRO-SANT'ANA, H.M. Vitamina C, carotenoides, fenólicos totais e atividade antioxidante de goiaba, manga e mamão procedentes da Ceasa do Estado de Minas Gerais. Acta Scientiarum: Health Sciences, Maringá, v.33, n.1, p.89-98, 2011.

SANTOS, V.B. dos; SILVA, E.K.N. da; OLIVEIRA, L.M.A. de. Low cost in situ digital image method, based on spot testing and smartphone images, for determination of ascorbic acid in Brazilian Amazon native and exotic fruits. Food Chemistry, Londres, v.285, p.340-346, 2019.

SILVA, N.A.; RODRIGUES, E.; DE ROSSO, V.V. Phenolic compounds and carotenoids from four fruits native from the Brazilian Atlantic forest. Journal of Agricultural and Food Chemistry, Washington, v.62, n.22, p.5072-5084, 2014.

SILVA, M.M.M. da; SILVA, E.P. da; SILVA, F.A. da; OGANDO, F.I.B.; AGUIAR, C.L. de; DAMIANI, C. Physiological development of cagaita (Eugenia dysenterica). Food Chemistry, Londres, v.217, p.7480, 2017. 
TULER, A.C.; CARRIJO, T.T.; FERREIRA, M.F.S.; ZOLA, F.G.; RODRIGUES, A.C.; OLIVEIRA, B.D.; PEIXOTO, A.L. Flora of Espírito Santo: Psidium SACRAMENTO, N.T.B.; TAYLOR, J.G.; PINTO, U.M.; (Myrtaceae). Rodriguésia, Rio de Janeiro, v.68, n.5, BERTOLDI, M.C. Mineral and centesimal contents, p.1791-1805, 2017. antioxidant activity and antimicrobial action of phenolic compounds from Eugenia brasiliensis Lam. Pulp. Food Science and Technology, Campinas, v.39, p.378-385, 2019. Supl. 2. 